\title{
Influence of Trichoderma reesei or Saccharomyces cerevisiae on performance, ruminal fermentation, carcass characteristics and blood biochemistry of lambs fed Atriplex nummularia and Acacia saligna mixture
}

\author{
M.H. Ahmed a , M.M.Y. Elghandour ${ }^{\text {b }}$, A.Z.M. Salem ${ }^{\text {b,* }}$, H.S. Zeweil ${ }^{\text {a }}$, A.E. Kholif ${ }^{\text {, }}$, \\ A.V. Klieve ${ }^{\text {d, A.M.A. Abdelrassol }}{ }^{\mathrm{a}}$ \\ ${ }^{a}$ Animal and Fish Production Department, Faculty of Agriculture (Saba Basha), Alexandria University, Alexandria, Egypt \\ ${ }^{\mathrm{b}}$ Facultad de Medicina Veterinaria y Zootecnia, Universidad Autónoma del Estado de México, Estado de México, Mexico

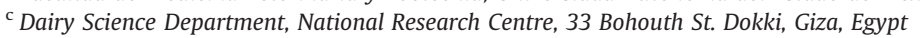 \\ d School of Agriculture and Food Sciences, University of Queensland, Gatton Campus, Gatton, Queensland 4343, Australia
}

\section{A R T I C L E I N F O}

\section{Article history:}

Received 29 October 2014

Received in revised form

22 June 2015

Accepted 23 June 2015

\section{Keywords:}

Acacia

Atriplex

Fungus

Halophytes

Lambs

\begin{abstract}
A B S T R A C T
The aim of this study was to evaluate whole substitution of Egyptian berseem hay (Trifolium alexandrinum) with a mixture of Atriplex nummularia and Acacia saligna (1:1 DM) in the diet of Barki lambs for 70 days. Thirty six lambs $(27.0 \pm 0.89 \mathrm{~kg}$ initial BW) were divided into four treatment groups of nine lambs each and fed: (1) the Control group with no substitution (70\% concentrate mixture and 30\% berseem hay, DM basis), (2) A. nummularia and A. saligna mixture without fungal treatment (treatment group AU), or (3) Trichoderma reesei treated A. nummularia and A. saligna mixture (treatment group AF), or (4) A. nummularia and A. saligna mixture supplemented with Saccharomyces cerevisiae at $0.5 \mathrm{~g} / \mathrm{kg} \mathrm{DM}$ of feed (treatment group AS) replaced $100 \%$ of berseem hay in the diet. Live-weight change, rumen fermentation parameters, blood chemistry, carcass characteristics and intestinal histology were investigated. Significant $(P<0.05)$ interactions occurred between diet and period for feed conversion efficiency and blood serum urea. Lambs in the AS treatment consumed less $(P<0.05)$ feed than lambs in the AF treatment, with no difference between the other treatments $(P>0.05)$. Lambs fed AF and AU diets had lower $(P<0.05)$ feed conversion efficiency than lambs fed the AS and Control diets. Lambs fed AF and AS had increased $(P<0.05)$ volatile fatty acid production compared to Controls. Blood albumin and urea concentrations increased $(P<0.05)$ with lambs in AS treatment compared to lambs in the other treatments, while lambs fed AF had lower $(P<0.05)$ cholesterol and glucose concentrations compared to the Controls. The AS lambs had the highest $(P<0.05)$ dressing percentage. Decreased intramuscular fat weights were obtained with lambs fed halophytes compared to Control lambs. Histology of the ileum, sub mucosa and Peyer's patches were normal in all lambs. In conclusion, untreated halophyte mixtures of A. nummularia and A. saligna (at 1:1 DM) can be substituted for berseem hay without negative effects on performance while treatment with $S$. cerevisiae may improve performance and, like $T$. reesei, change certain biochemical responses.
\end{abstract}

(c) 2015 Elsevier B.V. All rights reserved.

\section{Introduction}

There is an increased awareness of the value of halophytic or saltbush forage shrubs as animal feeds in arid and semi-arid regions (Alsersy et al., 2015; Salem et al., 2015). Halophytes are widely distributed, and at high density, in many areas under

\footnotetext{
*Corresponding author. Fax: +5217221806194.

E-mail address: asalem70@yahoo.com (A.Z.M. Salem).
}

conditions of water shortage and high soil salinity. Feeding halophytes to ruminants is a possible solution to feed shortages in these areas (Ahmed et al., 2015; Alsersy et al., 2015; Salem et al., 2015).

Saltbush (Atriplex spp.) and shrubs including wattles (Acacia spp.) have received increased interest as livestock feed, especially in arid zones of North Africa and the northern region of Egypt (Ahmed et al., 2015; Alsersy et al., 2015; Salem et al., 2015). However, these species accumulate high concentrations of salt, oxalates and secondary plant compounds in their leaves 
(Papanastasis et al., 2008) making them less palatable and of lower nutritive value (Ben Salem et al., 2010). The degree of impact that this has will depend on the level of inclusion in the diet. Saltbushes and shrubs, in general, contain high levels of crude protein (CP), which is reasonably digestible, soluble carbohydrates and a relatively high mineral content (Al-Owaimer et al., 2008). A deficiency of available metabolisable energy and the rapid fermentation of $\mathrm{CP}$ in the rumen may be reasons for poor utilisation by ruminants. Most of the $\mathrm{CP}$ in saltbushes and shrubs is associated with non-protein nitrogen (N) compounds (Le Houérou, 1992) which can be converted into microbial protein or ammonia in the rumen dependant on the availability of metabolisable energy (Pearce et al., 2010). Therefore, supplementation with energy sources such as, barley grains, corn grains or molasses have been suggested as strategies to stimulate intake and improve the utilization of ruminal ammonia-N by rumen microorganisms when these shrubs are fed (Ahmed et al., 2015).

Acacia saligna is a successful species of colonising Acacia, due to its tolerance of dry environmental conditions, and its ability to produce large amounts of biomass with a relatively high CP content and nutritive value (Degan et al., 1997). However, it cannot be used as a sole nutrient source due to its high content of condensed tannins (Degan et al., 1997), which precipitate proteins and form indigestible tannin-protein complexes (Degan et al., 1995). It also complexes with soluble carbohydrates, cellulose, hemicelluloses and amino acids resulting in reduced digestibility of these substrates (Salem, 2005). Atriplex nummularia is a perennial halophyte shrub which is palatable; it remains green even during prolonged drought and maintains a relatively high $\mathrm{CP}$ content throughout the year. Ben Salem et al. (2010) in their review showed that Atriplex spp. contain a balanced amino acid profile. Khalil et al. (1986) stated that the essential amino acids, especially methionine and lysine are higher in Atriplex than in cereal proteins.

Mixing more than one type of halophyte may improve their utilization as animal feed. Abd El-Rahman et al. (2014) mixed A. saligna and Brassica nigra hay in the diet of sheep and goats, and stated that supplementation of both plants with barley grain can enhance performance of both sheep and goats. In addition, Shaker (2014) mixed A. nummularia, Sorghum bicolour and Pearl millet in the diet of Barki sheep and concluded that feeding a mixture of salt tolerant plants improved lamb performance (live-weight gain). Appropriate mixing of different halophyte species, based on their complementary nutritive profiles, could reduce the negative consequences of anti-nutritional factors, and thus improve animal performance (Shaker, 2014). Gihad and El Shaer (1994) stated that feeding ruminants on saltbushes (Atriplex spp.) combined with low salt forage (A. saligna) is desirable to dilute the high salt content of Atriplex spp.

The yeast Saccharomyces cerevisiae can be used as a probiotic, and has been shown to specifically alter the rumen environment, and enhance microbial activity (Elghandour et al., 2014, 2015). Yeast appears to play a role in removing traces of oxygen that may be toxic to rumen bacteria thereby increasing the number of total anaerobic and cellulolytic bacteria (Jouany, 2001). The treatment of feeds with fungi, through enzymatic action, can remove antinutritional factors from feed, and improve the nutritive value of the feed (Fayed, 2009; Khattab et al., 2013; Kholif et al., 2014). Fungal lignocellulolytic enzymes break the polysaccharide-lignin complex resulting in enhanced digestibility and improved animal performance (Kholif et al., 2014). Therefore, the current study aimed to evaluate the impact of replacing berseem hay, in a complete diet, with a mixture of equal parts Atriplex and Acacia that had been either left untreated or supplemented with fungal probiotic treatments.

\section{Materials and methods}

Animals were cared and handled in accordance with the Guide for the Care and Use of Agricultural Animals in Agricultural Research and Teaching (FASS, 1999).

\subsection{Plant forage preparation}

Leaves and stems of fresh nursery plants of saltbush $A$. nummularia and wattle A. saligna were collected from the north-western desert region of Borg El-Arab, Alexandria (Egypt), dried and chopped into $3-5 \mathrm{~cm}$ lengths and stored in a dry environment.

\subsection{Fungal treatment of forage}

Trichoderma reesei was obtained from the Animal Production Research Institute, Cairo, Egypt. The fungus was maintained on potato dextrose agar in petri dishes at ambient temperature (22$\left.25^{\circ} \mathrm{C}\right)$.

The mixture of $A$. nummularia and $A$. saligna $(1: 1 \mathrm{DM})$ was autoclaved (Tuttnauer USA Co. Ltd., NY, USA) at $121^{\circ} \mathrm{C}$ and $1.5 \mathrm{psi}$ for $15 \mathrm{~min}$ to destroy any microbes. The content was allowed to cool and later inoculated with the spores of $T$. reesei at a rate of $40 \mathrm{~mL}$ of the spore suspension containing $10^{7}$ spores per $\mathrm{mL} / \mathrm{kg}$ DM of autoclaved $A$. nummularia and A. saligna mixture. The inoculated substrates were then incubated at ambient temperature for 10 days. By the end of the incubation period, the forages were fully covered with the fungus. They were then oven dried at $70{ }^{\circ} \mathrm{C}$ in a forced air drying oven (Cascade TEK's Model TFO-10, OR, USA) for $24 \mathrm{~h}$ so as to stop fungal growth and prevent further denaturation of proteins.

\subsection{Diets}

Lambs were fed one of four diets. The Control diet consisted of a mixed concentrates mixture based on barley, wheat bran and soybean meal mixed together and then combined with Egyptian berseem hay (Trifolium alexandrinum) at a ratio of 70:30 on a DM basis. The treatment diets were the same as the Control, but the berseem hay was totally replaced with either $A$. nummularia and $A$. saligna mixture without fungal treatment (treatment group $A U$ ), or $A$. nummularia and $A$. saligna mixture treated with $T$. reesei (treatment group $\mathrm{AF}$ ), or $A$. nummularia and $A$. saligna mixture supplemented with $S$. cerevisiae (Brookside Agra, USA; contained $8 \times 10^{8} \mathrm{CFU} / \mathrm{g}$ ) at $0.5 \mathrm{~g} / \mathrm{kg} \mathrm{DM}$ of feed (treatment group AS). Ingredients and chemical composition of the experimental diets are presented in Tables 1 and 2, respectively.

\subsection{Animals and feeding}

Thirty six Barki lambs with initial BW $27.0 \pm 0.89 \mathrm{~kg}$ and final BW $37.2 \pm 0.43 \mathrm{~kg}$ and at approximately 13 months of age were used. Prior to the experiment, the lambs were treated for internal and external parasites. Lambs were divided into four treatment groups of nine lambs each and fed diets as detailed previously. These diets were formulated to meet their maintenance requirements (NRC, 1985). Before the experiment, lambs were fed on a diet of concentrates and berseem hay at a ratio of $1: 1$ on a DM basis. Lambs were adapted to the experimental diets for two weeks and fed for a total of 70 days. Lambs were fed twice daily at 08:00 and 16:00 h. Berseem hay or A. nummularia and A. saligna hays were offered first followed by concentrates.

\subsection{Animal performance}

Lambs were individually weighed every two weeks prior to 
Table 1

Ingredients $(\mathrm{g} / \mathrm{kg} \mathrm{DM})$ of the experimental diets ${ }^{\mathrm{a}}$ containing Atriplex nummularia and Acacia saligna (1:1 DM) treated with Trichoderma reesei or Saccharomyces cerevisiae.

\begin{tabular}{|c|c|c|c|c|}
\hline & Control & AU & $\mathrm{AF}$ & AS \\
\hline \multicolumn{5}{|l|}{ Forages } \\
\hline Berseem (Trifolium alexandrinum) hay & 300 & 0 & 0 & 0 \\
\hline Atriplex nummularia & 0 & 150 & 150 & 150 \\
\hline Acacia saligna & 0 & 150 & 150 & 150 \\
\hline \multicolumn{5}{|l|}{ Concentrates } \\
\hline Barley & 265 & 265 & 265 & 265 \\
\hline Wheat bran & 250 & 250 & 250 & 250 \\
\hline Soybean meal & 100 & 100 & 100 & 100 \\
\hline Molasses & 55 & 55 & 55 & 55 \\
\hline Limestone $\left(\mathrm{NaHCO}_{3}\right)$ & 20 & 20 & 20 & 20 \\
\hline Salt & 5 & 5 & 5 & 5 \\
\hline Mineral and vitamin mixture ${ }^{\mathrm{b}}$ & 5 & 5 & 5 & 5 \\
\hline
\end{tabular}

a The diets contained $30 \%$ berseem hay $+70 \%$ concentrate mixture (Control), $\mathrm{AU}=15 \%$ Atriplex $+15 \%$ Acacia $+70 \%$ concentrate mixture (negative control); $\mathrm{AF}=\mathrm{AU}$ treated with Trichoderma reesei, and $\mathrm{AS}=\mathrm{AU}$ supplemented with Saccharomyces cerevisiae as a probiotic at $0.5 \mathrm{~g} / \mathrm{kg}$ DM of feed.

${ }^{\mathrm{b}}$ Mineral and vitamin mixture (/kg): Cu, $8 \mathrm{mg}$; Fe, $35 \mathrm{mg}$; Mn, $80 \mathrm{mg}$; Se, $0.6 \mathrm{mg}$; Zn, $60 \mathrm{mg}$; vitamin A, 12,000 IU; vitamin $\mathrm{D}_{3}$, $2500 \mathrm{ICU}$; vitamin E, $20 \mathrm{IU}$; menadione, $1.3 \mathrm{mg}$; riboflavin, $5.5 \mathrm{mg}$; vitamin $\mathrm{B}_{12}, 10 \mu \mathrm{g}$; vitamin $\mathrm{B}_{6}, 3 \mathrm{mg}$; thiamine, $3 \mathrm{mg}$; folic acid, $1.0 \mathrm{mg}$; D-biotin, $50 \mu \mathrm{g}$; Ca-pantothenate, $1 \mathrm{mg}$; nicotinic acid, $50 \mathrm{mg}$; choline chloride, $600 \mathrm{mg}$.

morning feeding. The feed consumption (DM basis) was calculated daily by the difference between offered and refused feed before morning feeding. Feed conversion efficiency was calculated as kilograms of body weight gain to kilograms of feed consumed (DM basis). Water consumption was measured daily and a bucket with the same amount of water offered was placed in the animal shed to estimate water evaporation for the calibration of water consumption.

\subsection{Blood chemistry}

Four lambs per treatment were randomly chosen for blood sample collection from each treatment group at day 35 and day 70 . About $10 \mathrm{~mL}$ of blood from each lamb was collected into a clean dry tube (BD Vacutainer ${ }^{\circledR}$ Tubes, Franklin Lakes, NJ, USA) from the jugular vein immediately before morning feeding. Heparin was used as an anticoagulant. Heparinized blood samples were centrifuged at $4000 \mathrm{~g}$ at $4{ }^{\circ} \mathrm{C}$ for $20 \mathrm{~min}$. Plasma was separated into clean dried glass vials and frozen at $-20^{\circ} \mathrm{C}$ for later analysis.

\subsection{Slaughter procedure}

All lambs were slaughtered after being on the experimental diets for 70 days. Prior to slaughter, lambs were fasted for $18 \mathrm{~h}$ and then slaughtered at a commercial slaughterhouse. Slaughter body weight was obtained for all lambs immediately after death. Also, the hot carcass weight including tail fat and kidney fat was determined following dressing. Heads, legs, lungs, hides, hearts, livers, and full digestive tract were weighed. Tail and kidney fat were left on the carcass. Weight of gut content was subtracted from slaughter weight to obtain the empty body weight; dressing was expressed as a percent of slaughter weight. The best ribs (9th11th ribs) were separated from the right side of each carcass and analysed for meat, bone and fat proportions. Meat samples were ground through a $4 \mathrm{~mm}$ sieve. From this, $30-40 \mathrm{~g}$ of a mixed sample from all lambs in each treatment was placed in a plastic bag and stored at $-20^{\circ} \mathrm{C}$ for chemical analysis.

\subsection{Ruminal fermentation parameters}

Rumen samples were collected at slaughter, according to the method described in Ahmed et al. (2015) and Kholif et al. (2015). About $100 \mathrm{~mL}$ of rumen contents was collected and strained through four layers of cheesecloth. Ruminal pH was immediately determined using a digital pH metre (GLP 22, Crison Instruments, Barcelona, Spain). Strained rumen samples were placed into $45-\mathrm{mL}$ glass bottles with a few drops of toluene and paraffin oil added to just cover the surface, prior to storage at $-18^{\circ} \mathrm{C}$ for ammonia- $\mathrm{N}$ and volatile fatty acid (VFA) analyses.

\subsection{Histological parameters}

According to the method of Culling (1983), immediately after necropsy, tissue specimens from the small intestine (ileum) were rapidly fixed in $10 \%$ neutral buffered formalin solution for at least $24 \mathrm{~h}$. The fixed specimens were processed through the conventional paraffin embedding technique of dehydration through ascending grades of ethanol, cleared in chloroform and embedded in paraffin wax at $60{ }^{\circ} \mathrm{C}$. Paraffin blocks were prepared, from which $7 \mu \mathrm{m}$ thick sections were cut on a freeze microtome (Thermo

Table 2

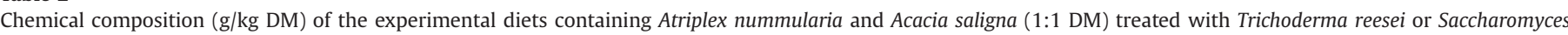
cerevisiae.

\begin{tabular}{|c|c|c|c|c|c|c|c|}
\hline & \multicolumn{3}{|l|}{ Forages source } & \multicolumn{4}{|c|}{ Experimental diets $^{\mathrm{a}}$} \\
\hline & Berseem hay & Atriplex nummularia & Acacia saligna & Control & $\mathrm{AU}$ & $\mathrm{AF}$ & AS \\
\hline Organic matter & 902 & 754 & 863 & 890 & 872 & 804 & 872 \\
\hline Crude protein & 167 & 189 & 176 & 155 & 161 & 170 & 161 \\
\hline Ether extract & 20 & 11 & 12 & 17 & 18 & 18 & 18 \\
\hline Non-structural carbohydrates ${ }^{\mathrm{b}}$ & 294 & 89 & 236 & 439 & 390 & 245 & 390 \\
\hline Neutral detergent fibre & 421 & 465 & 439 & 126 & 145 & 371 & 145 \\
\hline Acid detergent fibre & 281 & 265 & 238 & 232 & 229 & 215 & 229 \\
\hline \multicolumn{8}{|l|}{ Secondary compounds } \\
\hline Total phenolics & & 113 & 61 & & & & \\
\hline Saponins & & 124 & 24 & & & & \\
\hline Alkaloids & & 2.3 & 3.2 & & & & \\
\hline Aqueous fraction ${ }^{c}$ & & 475 & 68 & & & & \\
\hline
\end{tabular}

a The diets contained $30 \%$ berseem hay $+70 \%$ concentrate mixture (Control), $\mathrm{AU}=15 \%$ Atriplex $+15 \%$ Acacia $+70 \%$ concentrate mixture (negative control); $\mathrm{AF}=\mathrm{AU}$ treated with Trichoderma reesei, and $\mathrm{AS}=\mathrm{AU}$ supplemented with Saccharomyces cerevisiae as a probiotic at $0.5 \mathrm{~g} / \mathrm{kg} \mathrm{DM}$ of feed.

b Non-structural carbohydrates calculated by difference [100-(\%NDF+\%CP $\% \mathrm{EE}+\% \mathrm{ash})]$.

c Aqueous fraction (lectins, polypeptides and starch). 
Scientific ${ }^{\text {тм }}$ HM 325 Rotary Microtome, Waltham, MA, USA). These sections were stained with Haematoxylin and Eosin before microscopic examination.

\subsection{Chemical analyses}

Conventional analysis of feed samples was carried out according to AOAC (1997) for DM, ash, N and ether extract (EE). The neutral detergent fibre (NDF) and acid detergent fibre (ADF) were analysed by the method of Van Soest et al. (1991) using ANKOM ${ }^{200}$ Fibre Analyser unit (ANKOM Technology Corporation, Macedon, NY, USA). The NDF was assayed without use of an alpha amylase but with sodium sulphite. Both NDF and ADF are expressed without residual ash. Proximate analysis of meat samples was according to AOAC (1997).

The secondary metabolite concentrations of both plants were determined as previously described by Salem et al. (2014).

Ruminal ammonia-N concentration was determined according to the method of Gips and Wibbens-Alberts (1968). Ruminal VFA concentration was determined as described by Warner (1964).

Blood plasma samples were analysed calorimetrically for total protein, albumin, urea-N, glucose, total cholesterol, high density lipoproteins (HDL) and low density lipoproteins (LDL), using specific kits obtained from Stanbio Laboratory (Boerne, Texas, USA) according to the procedure outlined by the manufacturer. Globulin concentration was calculated by subtracting the values of albumin from those of total proteins.

\subsection{Statistical analysis}

Dry matter intake, water consumption, daily weight gain and feed conversion efficiency were analysed with diet type, period (as repeated measurements) and their interaction (diet $\times$ period) as the experimental factors having fixed effects using PROC MIXED of SAS (SAS Inst. Inc. Cary, NC, USA, 2002) in two-way ANOVAs according to the following statistical model:

$Y_{i j k}=\mu+D_{i}+T_{j}+(D \times T)_{i j}+A_{k}+e_{i j k}$

where $Y_{i j k}$ is the dry matter intake, water consumption, daily weight gain or feed conversion efficiency, respectively, $\mu$ is the overall mean, $D_{i}$ is the fixed effect of diet $(i=4), T_{j}$ is the fixed effect of period $(j=5),(D \times T)_{i j}$ is the fixed effect of interaction between diet and period, $A_{k}$ is the random effect of animal $(k=9)$, and $e_{i j k}$ is the random residual error. Significance was declared at a level of $P<0.05$ and trend at $P \leq 0.10$.

The remaining data obtained were analysed using one-way ANOVAs according to the following statistical model:

$Y_{i j}=\mu+D_{i}+A_{j}+e_{i j}$

where $Y_{i j}$ is the observation, $\mu$ is the overall mean, $D_{i}$ is the fixed effect of diet, $A_{j}$ is the random effect of animal, and $e_{i j}$ is the random residual error. The comparisons among treatments were performed with Duncan's multiple range test.

\section{Results}

\subsection{Feed intake, water consumption and body weight gain}

No interaction occurred $(P>0.05)$ between period $\times$ diet for DM intake, water consumption and daily weight gain; however, significant interaction in feed conversion efficiency did occur. Lambs in the AS group consumed less feed than those in the AF group $(P<0.05)$ with no differences $(P>0.05)$ between AF, AU and Control lambs (Table 3).

Lambs fed different diets consumed the same amount of water and achieved the same daily weight gain $(P>0.05)$ during the whole experiment (Table 3).

Significantly decreased feed conversion efficiency was observed $(P<0.05)$ in lambs from the AF and AU treatment groups compared to the Control and AS groups. There was no significant difference $(P>0.05)$ between the AS and Control treatment groups (Table 3 and Fig. 1).

\subsection{Ruminal fermentation and blood parameters}

Lambs in the AF and AS treatment groups had higher VFA concentrations than the Controls. There were no differences in ruminal ammonia-N between groups (Table 4).

As shown in Table 4 , interactions between diet $\times$ period occurred $(P<0.01)$ for urea with no significant interactions $(P>0.05)$ with other serum parameters. Lambs in the AS treatment had more serum albumin (after 10 weeks) and urea (after 5 weeks) compared to Control lambs. Increased globulin (after 5 weeks) with decreased cholesterol (after 5 weeks) and glucose concentrations (after 10 weeks) being observed in the AF group lambs as compared to Control lambs. No effect was observed $(P>0.05)$ between any group of lambs in terms of blood total protein, LDL and HDL (data not shown).

\subsection{Carcass characteristics}

No significant differences were observed $(P>0.05)$ between treatments in slaughter body weight, empty and full alimentary tract, gut content, empty body weight and carcass weights. Moreover, organ weights of tail, trachea, feet, head, mesentery weights, pelt, spleen, liver, heart and heart fat were the same in all lambs. Lambs in the AS and AF groups had a significantly higher dressing percentage compared to the Control lambs. In addition, no differences were observed $(P>0.05)$ between different

Table 3

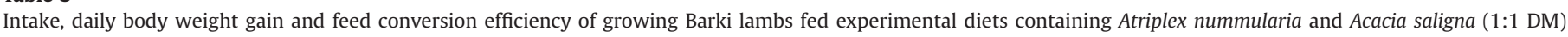
treated with Trichoderma reesei or Saccharomyces cerevisiae.

\begin{tabular}{|c|c|c|c|c|c|c|c|c|}
\hline & \multicolumn{4}{|c|}{ Experimental diets ${ }^{1}$} & \multirow[t]{2}{*}{ SEM } & \multicolumn{3}{|c|}{$P$ value } \\
\hline & Control & AU & $\mathrm{AF}$ & AS & & Diet & Period & Diet $\times$ period \\
\hline DM intake (g/lamb/day) & $1043^{\mathrm{ab}}$ & $1019^{\mathrm{ab}}$ & $1070^{\mathrm{a}}$ & $943^{\mathrm{b}}$ & 33.6 & 0.037 & $<0.001$ & 0.408 \\
\hline Water consumption (L/lamb/day) & 3.4 & 3.9 & 3.8 & 3.8 & 0.15 & 0.075 & 0.954 & 1.000 \\
\hline Daily weight gain (g/lamb/day) & 150 & 139 & 144 & 149 & 5.6 & 0.470 & 0.005 & 0.661 \\
\hline Feed conversion efficiency ( $\mathrm{kg}$ live weight gain $/ \mathrm{kg}$ feed) & $0.134^{\mathrm{a}}$ & $0.117^{\mathrm{b}}$ & $0.111^{\mathrm{b}}$ & $0.137^{\mathrm{a}}$ & 0.0042 & 0.001 & $<0.001$ & $<0.001$ \\
\hline
\end{tabular}

${ }^{\mathrm{a}, \mathrm{b}}$ Means within the same row with different superscripts differ significantly among treatments $(P<0.05)$.

${ }^{1}$ The diets contained $30 \%$ berseem hay $+70 \%$ concentrate mixture (Control), $\mathrm{AU}=15 \%$ Atriplex $+15 \%$ Acacia $+70 \%$ concentrate mixture (negative control); $\mathrm{AF}=\mathrm{AU}$ treated with Trichoderma reesei, and AS $=$ AU supplemented with Saccharomyces cerevisiae as a probiotic at $0.5 \mathrm{~g} / \mathrm{kg} \mathrm{DM}$ of feed. 


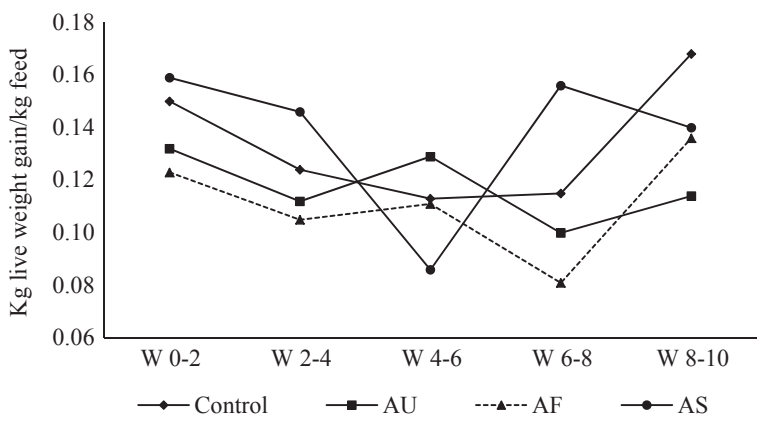

Fig. 1. Feed conversion efficiency of Barki lambs fed on the experimental diets across the experimental period from week 0 to week 10. SEM=0.004; $P<0.001$. Control $=30 \%$ berseem hay $+70 \%$ concentrate mixture, $A U=15 \%$ Atriplex $+15 \%$ Acacia $+70 \%$ concentrate mixture (negative control); $\mathrm{AF}=\mathrm{AU}$ treated with Trichoderma reesei, and $\mathrm{AS}=\mathrm{AU}$ supplemented with Saccharomyces cerevisiae as a probiotic at $0.5 \mathrm{~g} / \mathrm{kg}$ DM feed.

treatment groups in the chemical composition of the meat or for physical composition, with the exception of intramuscular fat where lambs in the AF, AS and AU groups had significantly less intramuscular fat compared to the Control lambs (Table 5).

\subsection{Intestinal histopathology}

Lambs fed the halophytic diets (i.e. in treatments $\mathrm{AU}, \mathrm{AF}$ and AS) showed a normal intestinal histology when compared to Control lambs. All lambs showed normal histology of the ileum, sub mucosa and Peyer's patches. In comparison to the Control lambs (Fig. 2), microscopic examination of the ileum of AU group lambs (Fig. 3), AF group lambs (Fig. 4), AS group lambs (Fig. 5), did show some minor differences. The main difference being a reduction in the height of the ileal villi.

\section{Discussion}

\subsection{Feed intake and water consumption}

Throughout the experiment lambs fed the AS diet consumed less feed than lambs in the AF treatment. However, the AF diet had a lower (about 8\%) OM content than the AS diet. This level of ash may be acceptable for ruminal microbial activity and is a physiologically acceptable concentration. It was expected that feeding halophytes would decrease intake as a result of high concentrations of secondary plant metabolites, such as tannins, phenolics, steroids, cyanogenic substances and alkaloids that are known to decrease palatability (Moujahed et al., 2005). However, this was not observed in the current study, suggesting that palatability was not an issue. The fungal treatment is the most likely reason for the increased intake by lambs in the AF group compared to those receiving the AS diet. Improved feed intake and nutritive value from the halophytic plants may be a result of reduced anti-nutritional factors, through the removal or degradation of secondary plant compounds by the fungus (Fayed, 2009). Fungal treatment could, therefore, improve the potential for using halophytic plants as substitutes for more conventional feed sources.

Table 4

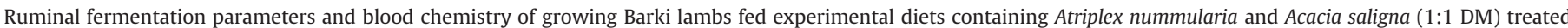
with Trichoderma reesei or Saccharomyces cerevisiae.

\begin{tabular}{|c|c|c|c|c|c|c|c|c|}
\hline & \multicolumn{4}{|c|}{ Experimental diets ${ }^{1}$} & \multirow[t]{2}{*}{ SEM } & \multicolumn{3}{|l|}{$P$ value } \\
\hline & Control & $\mathrm{AU}$ & $\mathrm{AF}$ & AS & & Diet & Period & Diet $\times$ period \\
\hline \multicolumn{9}{|l|}{ Ruminal fermentation parameters } \\
\hline Volatile fatty acids (mmol /100 mL) & $13^{\mathrm{b}}$ & $14^{\mathrm{ab}}$ & $15^{\mathrm{a}}$ & $15^{\mathrm{a}}$ & 0.8 & 0.010 & & \\
\hline Ammonia-N (mg / $100 \mathrm{~mL})$ & 114 & 115 & 136 & 138 & 10.1 & 0.249 & & \\
\hline \multicolumn{9}{|l|}{ Blood chemistry (mg/dL) } \\
\hline \multicolumn{9}{|l|}{ Albumin } \\
\hline After 5 weeks & 2.8 & 3.0 & 3.1 & 2.8 & 0.18 & 0.598 & & \\
\hline After 10 weeks & $2.7^{\mathrm{b}}$ & $2.9^{\mathrm{b}}$ & $2.8^{\mathrm{b}}$ & $3.2^{\mathrm{a}}$ & 0.11 & 0.012 & & \\
\hline SEM & 0.10 & 0.12 & 0.18 & 0.17 & & & & \\
\hline$P$ value & 0.542 & 0.445 & 0.322 & 0.103 & & 0.309 & 0.893 & 0.109 \\
\hline \multicolumn{9}{|l|}{ Globulin } \\
\hline After 5 weeks & $3.2^{\mathrm{ab}}$ & $2.6^{\mathrm{b}}$ & $3.8^{\mathrm{a}}$ & $3.3^{\mathrm{ab}}$ & 0.23 & 0.011 & & \\
\hline After 10 weeks & 3.4 & 2.9 & 2.9 & 3.2 & 0.21 & 0.417 & & \\
\hline SEM & 0.13 & 0.21 & 0.28 & 0.23 & & & & \\
\hline$P$ value & 0.447 & 0.340 & 0.046 & 0.766 & & 0.042 & 0.396 & 0.052 \\
\hline \multicolumn{9}{|l|}{ Cholesterol } \\
\hline After 5 weeks & $90^{\mathrm{a}}$ & $80^{\mathrm{a}}$ & $77^{\mathrm{b}}$ & $79^{a}$ & 3.1 & 0.031 & & \\
\hline After 10 weeks & $97^{\mathrm{a}}$ & $95^{\mathrm{a}}$ & $94^{\mathrm{a}}$ & $85^{\mathrm{b}}$ & 2.7 & 0.017 & & \\
\hline SEM & 3.2 & 3.4 & 2.5 & 2.4 & & & & \\
\hline$P$ value & 0.116 & 0.008 & 0.004 & 0.084 & & 0.002 & $<0.001$ & 0.217 \\
\hline \multicolumn{9}{|l|}{ Urea } \\
\hline After 5 weeks & $33^{c}$ & $39^{\mathrm{b}}$ & $45^{\mathrm{b}}$ & $59^{a}$ & 1.5 & $<0.001$ & & \\
\hline After 10 weeks & $32^{c}$ & $53^{b}$ & $75^{\mathrm{a}}$ & $52^{\mathrm{b}}$ & 2.3 & $<0.001$ & & \\
\hline SEM & 1.1 & 1.9 & 2.2 & 2.3 & & & & \\
\hline$P$ value & 0.459 & 0.001 & $<0.001$ & 0.068 & & $<0.001$ & $<0.001$ & $<0.001$ \\
\hline \multicolumn{9}{|l|}{ Glucose } \\
\hline After 5 weeks & 101 & 94 & 88 & 88 & 4.2 & 0.108 & & \\
\hline After 10 weeks & $65^{\mathrm{a}}$ & $61^{\mathrm{ab}}$ & $53^{\mathrm{b}}$ & $70^{\mathrm{a}}$ & 3.1 & 0.003 & & \\
\hline SEM & 3.7 & 4.3 & 3.4 & 3.1 & & & & \\
\hline$P$ value & $<0.001$ & $<0.001$ & $<0.001$ & 0.007 & & 0.009 & $<0.001$ & 0.053 \\
\hline
\end{tabular}

${ }^{\mathrm{a}, \mathrm{b}, \mathrm{c}}$ Means within in the same row with different superscripts differ significantly among treatments $(P<0.05)$.

${ }^{1}$ Diets contained $30 \%$ berseem hay $+70 \%$ concentrate mixture (Control), $\mathrm{AU}=15 \%$ Atriplex $+15 \%$ Acacia $+70 \%$ concentrate mixture (negative control); $\mathrm{AF}=\mathrm{AU}$ treated with Trichoderma reesei, and $\mathrm{AS}=\mathrm{AU}$ supplemented with Saccharomyces cerevisiae as a probiotic at $0.5 \mathrm{~g} / \mathrm{kg} \mathrm{DM}$ of feed. 
Table 5

Carcass characteristics, physical and chemical composition of the best ribs of growing Barki lambs fed experimental diets containing Atriplex nummularia and Acacia saligna (1:1 DM) treated with Trichoderma reesei or Saccharomyces cerevisiae.

\begin{tabular}{|c|c|c|c|c|c|c|}
\hline & \multicolumn{4}{|c|}{ Experimental diets ${ }^{1}$} & \multirow[t]{2}{*}{ SEM } & \multirow[t]{2}{*}{$P$ value } \\
\hline & Control & $\mathrm{AU}$ & $\mathrm{AF}$ & AS & & \\
\hline \multicolumn{7}{|l|}{ Carcass characteristics } \\
\hline Slaughter body weight (kg) & 37 & 37 & 37 & 37 & 1.2 & 0.352 \\
\hline Alimentary tract full $(\mathrm{kg})$ & 6.2 & 6.5 & 7.4 & 6.3 & 1.49 & 0.165 \\
\hline Alimentary tract empty $(\mathrm{kg})$ & 2.4 & 2.3 & 2.3 & 1.9 & 0.16 & 0.624 \\
\hline Gut content $(\mathrm{kg})$ & 4.0 & 4.2 & 5.1 & 4.4 & 0.40 & 0.524 \\
\hline Empty body weight (kg) & 27 & 27 & 27 & 27 & 1.3 & 0.851 \\
\hline Carcass weight $(\mathrm{kg})$ & 15 & 15 & 15 & 16 & 0.6 & 0.163 \\
\hline \multicolumn{7}{|l|}{ Dressing percentage } \\
\hline Based on slaughter weight & $40^{\mathrm{b}}$ & $40 \mathrm{~b}$ & $42^{\mathrm{a}}$ & $42^{\mathrm{a}}$ & 0.4 & 0.045 \\
\hline Based on empty body weight & $54^{\mathrm{c}}$ & $55^{\mathrm{b}}$ & $57^{\mathrm{b}}$ & $58^{\mathrm{a}}$ & 1.6 & 0.010 \\
\hline \multicolumn{7}{|c|}{ Physical composition of the 9th-11th ribs (kg) } \\
\hline Best ribs weight & 0.41 & 0.35 & 0.35 & 0.41 & 0.025 & 0.234 \\
\hline Meat weight & 0.21 & 0.18 & 0.19 & 0.23 & 0.020 & 0.356 \\
\hline Intramuscular fat weight & $0.10^{\mathrm{a}}$ & $0.08^{\mathrm{b}}$ & $0.05^{\mathrm{c}}$ & $0.06^{\mathrm{b}}$ & 0.001 & 0.010 \\
\hline Bone weight & 0.10 & 0.09 & 0.11 & 0.12 & 0.080 & 0.452 \\
\hline Best ribs area highest (mm) & 37 & 35 & 35 & 39 & 2.4 & 0.245 \\
\hline Best ribs area width $(\mathrm{mm})$ & 55 & 47 & 47 & 53 & 2.3 & 0.345 \\
\hline \multicolumn{7}{|c|}{ Chemical composition of the 9 th-11th ribs $(\mathrm{g} / \mathrm{kg})$} \\
\hline Dry matter & 516 & 486 & 484 & 502 & 29.1 & 0.423 \\
\hline Protein & 194 & 189 & 185 & 183 & 8.4 & 0.358 \\
\hline Ether extract & 282 & 317 & 324 & 307 & 25.7 & 0.426 \\
\hline Ash & 7.8 & 7.9 & 7.6 & 8.2 & 0.65 & 0.125 \\
\hline
\end{tabular}

a,b,c Means within in the same row with different superscripts differ significantly among treatments $(P<0.05)$.

${ }^{1}$ The diets contained 30\% berseem hay $+70 \%$ concentrate mixture (Control), $\mathrm{AU}=15 \%$ Atriplex $+15 \%$ Acacia $+70 \%$ concentrate mixture (negative control); $\mathrm{AF}=\mathrm{AU}$ treated with Trichoderma reesei, and $\mathrm{AS}=\mathrm{AU}$ supplemented with Saccharomyces cerevisiae as a probiotic at $0.5 \mathrm{~g} / \mathrm{kg}$ DM of feed.

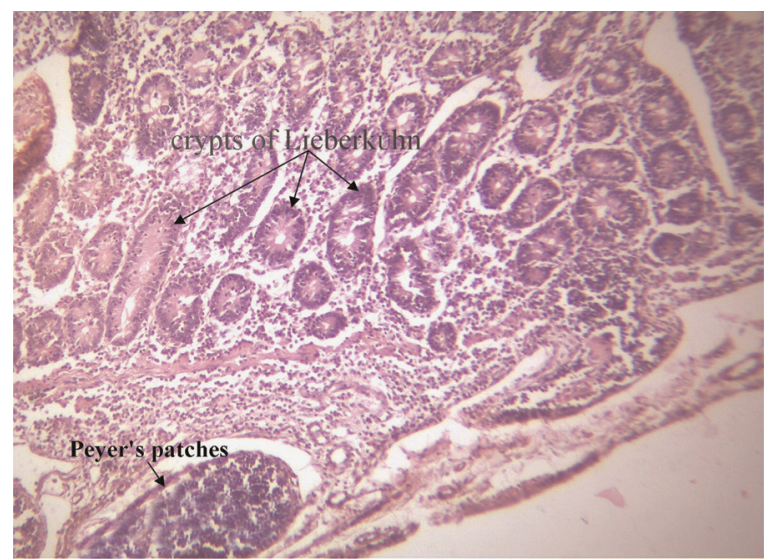

Fig. 2. Photomicrograph of ileum of Control Barki lambs stained with hematoxylin and eosin $(160 \times)$ : Normal histology.

In addition, feeding lambs diets that contain Atriplex or Acacia was expected to increase water consumption of the lambs due to the high content of salt in Atriplex and Acacia compared to berseem hay (Ahmed et al., 2015). However, there was no significant difference between groups, which may indicate an ability of lambs to adapt to the concentrations of salt in the feed on offer, or that the salt concentration was at an acceptable concentration.

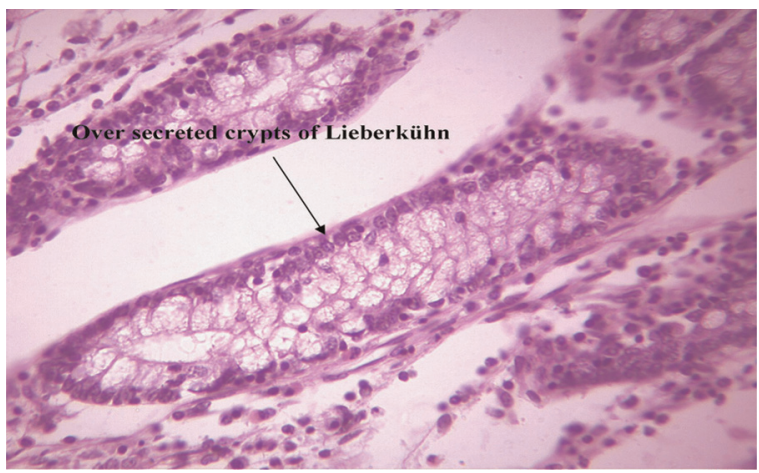

Fig. 3. Photomicrograph of ileum of AU Barki lambs stained with hematoxylin and eosin $(160 \times)$ : Normal histology.

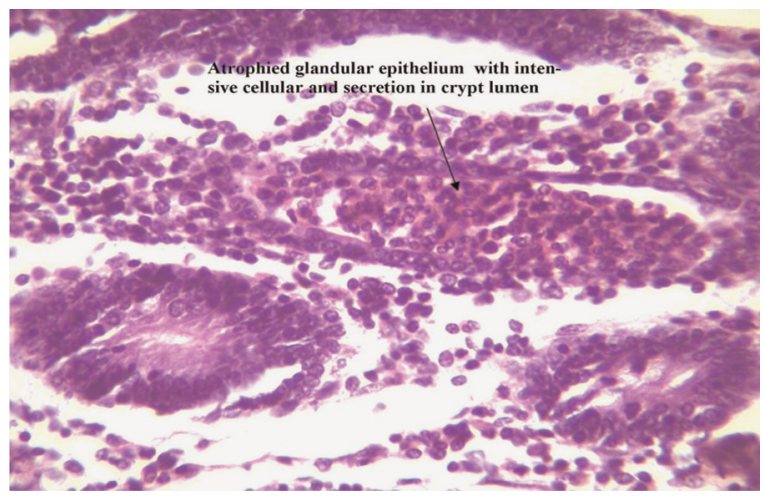

Fig. 4. Photomicrograph of ileum of AF Barki lambs stained with hematoxylin and eosin $(160 \times)$ : Normal histology.

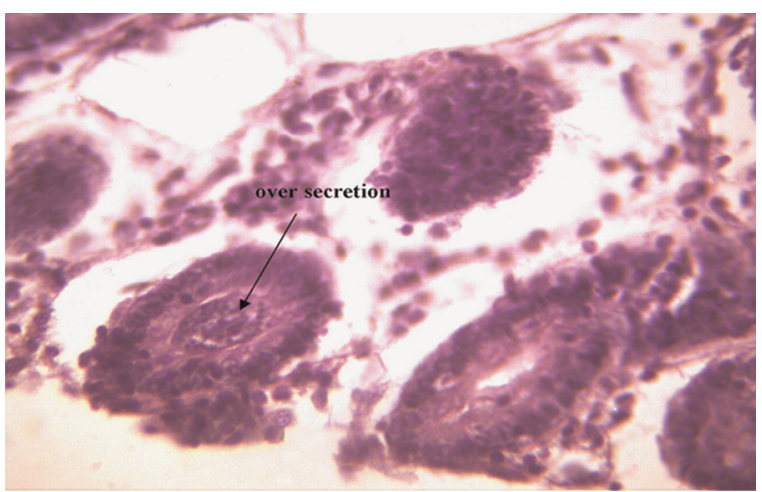

Fig. 5. Photomicrograph of ileum of AS Barki lambs stained with hematoxylin and eosin $(160 \times)$ : Normal histology.

\subsection{Rumen fermentation}

Improved ruminal fermentation in terms of VFA production was observed with the AF and AS treatments compared to Control. This suggests that the fermentation of diets with T. reesei or supplemented with $S$. cerevisiae was more efficient and produced more VFA than in the Control diet. Fayed (2009) showed that the treatment of $A$. saligna and Tamarix mannifera mixture with white rot fungi (Pleurotus ostreatus and Pleurotus florida) improved utilization and improved VFA concentrations of Barki rams.

\subsection{Blood chemistry}

The examination of blood parameters is recommended as a good way of assessing the health status of animals and the physiological, nutritional and pathological status of farm animals 
(Etim et al., 2013). Lambs in the AS treatment group had increased serum albumin and urea concentrations compared to Control lambs which reflects better protein digestion and utilization in these lambs. This is likely a result of higher protein content in these diets (halophytes versus berseem hay; Ahmed et al., 2015) and also a result of yeast addition (Elghandour et al., 2015). Increased plasma urea concentrations with diets containing halophytes (i.e., AS, AF, AU) possibly reflects the biodegradation of protein within the rumen (Kholif et al., 2014); however, ruminal ammonia-N concentration did not differ between treatments. Lambs in the AF group had lower cholesterol concentrations. Fayed et al. (2010) showed that blood cholesterol was reduced significantly with lambs fed an Atriplex and Acacia mixture treated with white rot fungus. These findings were attributed to the high tannin and saponins content of Atriplex and Acacia (Bravo et al., 1993). Saponins have been shown to be cholesterol absorption inhibitors causing a reduction in plasma cholesterol (Morehouse et al., 1999).

\subsection{Growth performance and feed conversion efficiency}

There were no differences between treatment groups in terms of liveweight change. An expected negative outcome of feeding Atriplex and Acacia on body weight gain, due to the presence of anti-nutritional factors, did not materialise (Ahmed et al., 2015; Alsersy et al., 2015).

Decreased feed conversion efficiency was observed with AU and AF lambs compared to AS and Control lambs. This is because AS and Control lambs consumed less feed while achieving almost the same daily gain as the other lambs. Improved feed conversion efficiency reflects better feed utilization with lambs in AS and Control groups compared to the other lambs. Increased feed conversion efficiency has also been observed in lambs fed A. nummularia at $15 \%$ of the diet and replacing the same amount of berseem hay (Ahmed et al., 2015).

\subsection{Carcass characteristics}

Increased dressing weight percentages (based on empty body weight) were obtained with the lambs fed halophytes. Mousa (2011) found that the dressing weight percentage of lambs fed experimental diets containing Atriplex and/or Acacia was higher than that of lambs fed diets without halophytes. Lambs fed the AS diet had an increased dressing percentage compared with lambs fed the AU diet. This result indicates that yeast may have a positive role in improving dressing percentage (Elghandour et al., 2015).

The physical characteristics of the best ribs (the 9th-11th ribs), with the exception of intramuscular fat, was not affected by the treatments imposed. The most likely reason for the reduction in fat deposition in lambs fed halophytes is the high protein:energy ratio, but may also be associated with secondary compounds in halophytes (Pearce et al., 2010). A high dietary protein:energy ratio will result in less fat deposition (Campbell, 1988). Al-Owaimer et al. (2008) found that lambs fed a complete diet containing Atriplex leucoclada had a significantly lower muscle fat percentage than those fed a control diet of alfalfa hay.

\subsection{Intestinal histopathology}

The main difference observed between diets was a reduction in the height of the ileal villi in lambs fed AU, AF and AS diets. Robins and Brooker (2005) stated that a marked increase in villous height and crypt depth were recorded for abomasal and intestinal samples from sheep fed Acacia aneura. It was clear that the feeding of untreated or treated Atriplex and Acacia led to minimal changes associated with over secretion of the intestinal glands, which may reduce the absorptive surface in the digestive tract. In this respect, Ahmed et al. (2015) observed that lambs fed halophytes (A. nummularia and/or A. saligna) instead of $50 \%$ of berseem hay (15\% of the diet) showed a normal histology of ileum, sub-mucosa and Peyer's patches.

\section{Conclusion}

The untreated halophyte mixture of A. nummularia and A. saligna (at 1:1 DM) can be substituted for berseem hay without loss of performance, while treatment with $S$. cerevisiae may improve performance and, like $T$. reesei, change certain biochemical responses. Treatment with $T$. reesei was more effective than $S$. cerevisiae supplementation for treating the halophyte mixture. However, a contribution to the improvement in the AF group could be attributed to autoclaving and drying the feed as the high temperatures and pressures may have altered some feed components.

\section{Conflict of interest}

All authors declare that there are no present or potential conflicts of interest among the authors and other people or organizations that could inappropriately bias their work.

\section{References}

Abd El-Rahman, H.H., Shoukry, M.M., Abedo, A.A., El-Nomeary, Y.A., Salman, F.M., Mohamed, M.I., 2014. Nutritional evaluation of some halophytic plants by range animals (sheep and goats). Glob. Vet. 13, 75-82.

Ahmed, M.H., Salem, A.Z.M., Zeweil, H.S., Sun, X.Z., Kholif, A.E., Elghandour, M.M.Y., Bahar, M.S.I., 2015. Growth performance and carcass characteristics of lambs fed halophytes as a partial or whole replacement of berseem hay. Small Rumin. Res. 128, 1-9.

Al-Owaimer, A.N., Zahran, S.M., Al-Bassam, B.A., 2008. Effect of feeding some types of Atriplex species in complete diet on meat quality and carcass characteristics of Najdi ram lambs. Int. J. Agric. Biol. 10, 105-108.

Alsersy, H., Salem, A.Z.M., Borhami, B.E., Olivares, J., Gado, H.M., Mariezcurrena, M D., Yacuot, M.H., Kholif, A.E., El-Adawy, M., Hernandez, S.R., 2015. Effect of Mediterranean saltbush (Atriplex halimus) ensilaging with two developed enzyme cocktails on feed intake, nutrient digestibility and ruminal fermentation in sheep. Anim. Sci. J. 86, 51-58.

Association of Official Analytical Chemists, 1997. Official Methods of Analysis, 16th ed. AOAC, Arlington, VA, USA.

Campbell, R.G., 1988. Nutritional constraints to lean tissue accretion in farm animals. Nutr. Res. Rev. 1, 233-253.

Ben Salem, H., Norman, H.C., Nefzaoui, A., Mayberry, D.E., Pearce, K.L., Revell, D.K. 2010. Potential use of oldman saltbush (Atriplex nummularia Lindl.) in sheep and goat feeding. Small Rumin. Res. 91, 13-28.

Bravo, L., Manas, E., Calixto, F.S., 1993. Dietary non extractable condensed tannins as indigestible compound: Effect on fecal weight and protein and fat excretion. J. Sci. Food Agric. 63, 63-68.

Culling, C.F., 1983. Handbook of Histopathological and Histochemica techniqes, 3rd ed. Butterworth, London.

Degan, A.A., Becker, K., Makkar, H.P.S., Borowy, N., 1995. Acacia saligna as fodder tree for desert livestock and the interaction of its tannins with fibre fractions. J. Sci. Food Agric. 68, 65-71.

Degan, A.A., Blankc, A., Beker, K., Kam, M., Benjamin, R.W., Makkar, H.P.S., 1997. The nutritive value of Acacia saligna and Acacia saligna for goats and sheep. J. Anim. Sci. 64, 253-259.

Elghandour, M.M.Y., Salem, A.Z.M., Martínez Castañeda, J.S., Camacho, L.M., Kholif, A.E., Vázquez Chagoyán, J.C., 2015. Direct-fed microbes: a tool for improving the utilization of low quality roughages in ruminants. J. Integr. Agric. 14 (3), 526-533.

Elghandour, M.M.Y., Vázquez Chagoyán, J.C., Salem, A.Z.M., Kholif, A.E., Martínez Castañeda, J.S., Camacho, L.M., Cerrillo-Soto, M.A., 2014. Effects of Saccharomyces cerevisiae at direct addition or pre-incubation on in vitro gas production kinetics and degradability of four fibrous feeds. Ital. J. Anim. Sci. 13, 295-301.

Etim, N.N., Enyenihi, G.E., Williams, M.E., Udo, M.D., Offiong, E.E.A., 2013. Haematological parameters: indicators of the physiological status of farm animals. Br. J. Sci. 10, 33-45.

Fayed, A.M., 2009. In vitro and In vivo evaluation of biological treated salt plants. Am. Eurasian J. Agric. Environ. Sci. 6, 108-118.

Fayed, A.M., El- Essawy, A.M., Eid, E.Y., Helal, H.G., Abdou, A.R., El Shaer, H.M., 2010 Utilization of berseem and Atriplex for feeding sheep under saline conditions of 
South Sinai, Egypt. J. Am. Sci. 6, 1447-1461.

FASS, 1999. Guide for the Care and Use of Agricultural Animals in Agricultural Research and Teaching. Federation for Animal Science Society, Champaign, IL.

Gihad, E.A., El Shaer, H.M., 1994. Nutritive value of halophytes. In: Squires, V.R., Ayoub, A.T. (Eds.), Halophytes as Resource for Livestock and Rehabilitation of Degraded Lands. Kluwer Academic Publishers, The Netherlands, pp. 281-284.

Gips, G.H., Wibbens-Alberts, M., 1968. Ammonia determination in blood using the TCA direct method. Clin. Chim. Acta 22, 183.

Khattab, H.M., Gado, H.M., Salem, A.Z.M., Camacho, L.M., El-Sayed, M.M., Kholif, A M., El-Shewy, A.A., Kholif, A.E., 2013. Chemical composition and in vitro digestibility of Pleurotus ostreatus spent rice straw. Anim. Nutr. Feed Technol. 13, 507-516.

Jouany, J.-P., 2001. A new look to yeast culture as probiotics for ruminants. Feed Mix 9, 17-19.

Khalil, J.K., Sawaya, W.N., Hyder, S.Z., 1986. Nutrient composition of Atriplex leaves grown in Saudi Arabia. J. Range Manag. 39, 104-107.

Kholif, A.E., Gouda, G.A., Morsy, T.A., Salem, A.Z.M., Lopez, S., Kholif, A.M., 2015 Moringa oleifera leaf meal as a protein source in lactating goat's diets: feed intake, digestibility, ruminal fermentation, milk yield and composition, and its fatty acids profile. Small Rumin. Res. . http://dx.doi.org/10.1016/j. smallrumres.2015.05.007

Kholif, A.E., Khattab, H.M., El-Shewy, A.A., Salem, A.Z.M., Kholif, A.M., El-Sayed, M. M., Gado, H.M., Mariezcurrena, M.D., 2014. Nutrient digestibility, ruminal fermentation activities, serum parameters and milk production and composition of lactating goats fed diets containing rice straw treated with Pleurotus ostreatus. Asian-Australas. J. Anim. Sci. 27, 357-364.

Le Houérou, H.N., 1992. The role of saltbushes (Atriplex spp) in arid land rehabilitation in the Mediterranean Basin: a review. Agrofor. Syst. 18, 107-148.

Morehouse, L.A., Bangerter, F.W., Deninno, M.P., Inskeep, P.B., Mccarthy, P.A., Pettini, J.L., Savoy, Y.E., Sugarman, E.D., Wilkims, R.W., Wilson, T.C., Woody, H.A., Zaccaro, L.M., Chandler, C.E., 1999. Comparison of synthetic saponin cholesterol absorption inhibitors in rabbits: evidence for non- stoichiometric, intestinal mechanisms of action. J. Lipid Res. 40, 464-474.

Moujahed, N., Salem, H.B., Kayouli, C., 2005. Effects of frequency of polyethylene glycol and protein supplementation on intake and digestion of Acacia cyanophylla Lindl. Foliage fed to sheep and goats. Small Rumin. Res. 56, 65-73.

Mousa, M.R.M., 2011. Effect of feeding Acacia as supplements on the nutrients digestion, growth performance, carcass traits and some blood constituents of Awassi lambs under the conditions of north Sinai. Asian J. Anim. Sci. 5, 102-117.

NRC, 1985. Nutrient Requirements of Sheep, 6th revised ed. National Academy Press, Washington, DC, USA.

Papanastasis, V.P., Yiakoulaki, M.D., Decandia, M., Dini-Papanastasi, O., 2008. Integrating woody species into livestock feeding in the Mediterranean areas of Europe. Anim. Feed Sci. Technol. 140, 1-17.

Pearce, K.L., Normanb, H.C., Hopkins, D.L., 2010. The role of saltbush-based pasture systems for the production of high quality sheep and goat meat. Small Rumin. Res. 91, 29-38.

Robins, C., Brooker, J.D., 2005. The effects of Acacia aneura feeding on abomasal and intestinal structure and function in sheep. Anim. Feed Sci. Technol. 121, 205-215.

Salem, A.Z.M., 2005. Impact of season of harvest on in vitro gas production and dry matter degradability of Acacia saligna leaves with inoculation from three ruminant species. Anim. Feed Sci. Technol. 123, 67-79.

Salem, A.Z.M., Kholif, A.E., Elghandour, M.M.Y., Hernandez, S.R., Domínguez-Vara, I. A., Mellado, M., 2014. Effect of increasing levels of seven tree species extracts added to a high concentrate diet on in vitro rumen gas output. Anim. Sci. J. 85, 853-860.

Salem, A.Z.M., Alsersy, H., Camacho, L.M., El-Adawy, M.M., Elghandour, M.M.Y., Kholif, A.E., Rivero, N., Alonso, M.U., Zaragoza, A., 2015. Feed intake, nutrient digestibility, nitrogen utilization, and ruminal fermentation activities in sheep fed Atriplex halimus ensiled with three developed enzyme cocktails. Czech J. Anim. Sci. 60, 185-194.

SAS, 2002. SAS User's Guide: Statistics. Ver 9.0. SAS Institute, Cary, NC, USA, p. 956.

Shaker, Y.M., 2014. Live body weight changes and physiological performance of Barki sheep fed salt tolerant fodder crops under the arid conditions of southern Sinai, Egypt. J. Am. Sci. 10, 78-88.

Van Soest, P.J., Robertson, J.B., Lewis, B.A., 1991. Methods for dietary fibre, neutral detergent fibre, and non-starch carbohydrates in relation to animal nutrition. J. Dairy Sci. 74, 3583-3597.

Warner, A.C.J., 1964. Production of volatile fatty acids in the rumen. Methods of measurements. Nutr. Abstr. Rev. 34, 339-352. 